Jurnal Widya Sastra Pendidikan Agama Hindu, Vol 4, No. 1, 2021

ISSN: 2656-7466

\title{
TRADISI PENGUBURAN MAYAT UMAT HINDU DI DESA TIGAWASA
}

\author{
Dewa Nyoman Sucita \\ STKIP Agama Hindu Singaraja, Singaraja, Indonesia \\ Email: dewasucita58@gmail.com
}

\begin{abstract}
Abstrak
Tujuan penelitian ini adalah untuk mengungkap keunikan-keunikkan dan kesederhanaan dari pelaksanaan penguburan mayat umat Hindu di desa Tigawasa. Untuk merampungkan penelitian ini digunakan beberapa metode antara lain, dalam mengumpulkan data digunakan metode wawancara dan metode kepustakaan. Dalam menganalisis data digunakan model analisis etnografi (ethnography analysis) dan hasilnya dipaparkan secara deskriptif. Adapun hasil penelitian yang diperoleh sebagai berikut. 1. Keunikan-keunikan Penguburan Mayat di Tigawasa antara lain: (1) tidak boleh membuat liang kubur sebelum upacara penguburan, karena kuburan tidak boleh dimasuki kecuali ada upacara penguburan/ngaben. (2) kuburan desa Tegawasa tidak disertai pura Dalem dan pura Prajapati, karena adanya awig-awig pelarangan memasuki wilayah kuburan. (3) sebagian sarana penguburan seperti bambu, kayu dan dedaunan yang diperlukan saat menguburkan harus dicari di areal kuburan tidak boleh dibawa dari rumah duka. (4) waktu penguburan tidak mencari dewasa ayu (hari baik) karena ada awig-awig desa, mayat tidak boleh didiamkan di rumah duka lebih dari 24 jam. 2. Tradisi penguburan meliputi beberapa tahapan upacara, yaitu: (1). Upacara saat meninggal ( Wawu lampus), (2). Upacara memandikan mayat (nyiramang); (3). Upacara mengusung mayat ke kuburan; (4). Upacara pembelian liang kubur dan (5). Upacara penguburan; 3. Sarana yang digunakan dalam penguburan mayat antara lain: 1). Ambuh; 2). Sisir/petat; 3). Sisig, 4). Waja; 5). Cermin/meka; 6). Uang kepeng; 7). Daun sirih; 8). Benang; 9). Mesui; 10). Daun sembung; 11). Pepage; 12). Daun penyalin/daun wi; 13). Blitbit; 14). Puung; 15). Cepu; 16). Air dan 17). Pakaian; sedangkan banten/upakara yang digunakan, diantaranya: 1). Sesagi (banten Punjung), 2). Banten aleman, dan 3). Canang gantal 21 buah.
\end{abstract}

Kata Kunci: Penguburan Mayat

\section{PENDAHULUAN}

Umat Hindu di Bali memiliki berbagai tradisi penguburan mayat, sehingga kita melihat berbagai perbedaan bentuk penguburan mayat antara desa yang satu dengan desa yang lain. Perbedaan-perbedaan ini mengakibatkan mulculnya berbagai pertanyaan, baik dari umat Hindu sendiri yang bersifat awam, maupun dari umat lain. Mengapa masyarakat Bali memiliki sistem penguburan yang berbeda-beda padahal menganut sistem kepercayaan atau agama yang sama yakni agama Hindu.

Pada dasarnya ada berbagai faktor yang menyebabkan perbedaan bentuk penguburan mayat ini. Pada umumnya dikatakan setiap pelaksanaan upacara dalam agama Hindu dipengaruhi oleh desa, kala dan patra. Orang-orang yang berada di dataran tinggi atau pegunungan/pedalaman memiliki tatacara penguburan yang 
berbeda dengan orang-orang yang tinggal di dataran rendah, di desa atau di perkotaan; seseorang yang meninggal pada hari biasa tentu penguburannya akan berbeda dengan orang yang meninggal pada saat warga melaksanakan upacara/pujawali di desanya; keadaan ekonomi keluarga yang meninggal juga besar pula pengaruhnya terhadap bentuk, jenis dan tingkatan upacara penguburan yang dapat dilaksanakan; sistem pelapisan sosial (wangsa/kasta, soroh, klen) juga berpengaruh terhadap bentuk penguburan mayat; pengaruh sekte-sekte yang pernah berkembang di Bali juga memberi warna perbedaan penguburan mayat dan tradisi yang telah dijalankan berabad-abad oleh warga desa yang tidak berani diubah oleh umat sampai saat ini.

Pada umumnya umat Hindu di Bali dalam menguburkan mayat, ada beberapa rangkaian yang dilaksanakan. Setelah seseorang meninggal, keluarga akan melapor terlebih dahulu kepada aparat desa adat, selanjutnya menentukan atau mencari hari baik untuk menguburkan. Dalam melaksanakan penguburan ada beberpa rangkaian upacara, yang dilaksanakan antara lain: 1. Melaksanakan upacara baru meninggal ( Wawu lampus); 2. Melaksanakan upacara memandikan mayat di rumah yang bersangkutan (nyiramang layon). Dalam nyiramang layon ini terdiri dari beberapa rangkaian, antara lain: a). menurunkan mayat dari balai-balai ke halaman rumah dan meletakkan di atas Pepaga (tempat memandikan mayat yang dibuat dari bambu), b). memasang reramuan, c). memasang Bablonyoh, d). memasang Eteh-eteh (daun intaran, baja, kaca dan lain-lain), e). memasang Bebek (boreh, anget-anget dan lainlain), f). memasang Lengewangi, g). memasang Kawangen, h) memasang wastra (pakaian orang meninggal), i). melaksanakan pebaktian/maktiang ke Surya, j). mempersembahkan banten arepan, k). melaksanakan mepegat dan I). melaksanakan melelet. Dengan selesainya melelet ini berarti rangkaian upacara Nyiramang ini selesai. 3. Melaksanakan penguburan mayat (mendem sawa). Dalam menguburkan mayat ini terdiri dari beberapa rangkaian, yaitu: a). membuka mayat dari tikar, pengelelet, dan tali kendit arte, b). diperciki tirta (tirta penglukatan, pengentas, merajan atau kawitan, c). membungkus mayat kembali lalu dikubur, d). mempersembahkan banten pada Hyang Prajapati, ibu Pertiwi dan penguasa kuburan (sedahan setra). Dan upacara yang terakhir atau yang ke-4, Sembahyang (Maktiang) dari para keluarga yang ditinggalkan (pratisentana). Dengan persembahyangan ini dilaksanakan maka rangkaian upacara penguburan telah berakhir (Team Penyusun, 2006: 172-179).

Terkait dengan rangkaian pelaksnaan penguburan mayat yang cukup panjang dan kompleks atau rumit tersebut, ternyata ada ditemukan pelaksanaan penguburan mayat yang sangat simple dan sederhana yang dilaksanakan oleh umat Hindu yang berada di desa Tigawasa, Kecamatan Banjar Kabupaten Buleleng. Tradisi penguburan mayat yang dilaksanakan oleh umat Hindu di desa Tigawasa tidak seperti apa yang dilaksanakan oleh umat Hindu pada umumnya. Masyarakat Hindu di Tigawasa memiliki tatacara sendiri yang berbeda dan cukup unik. Hal ini yang menarik, karena itu diangkat menjadi menjadi obyek penelitian, yang dirumuskan dalam judul penelitian, "Tradisi Penguburan Mayat Umat Hindu di Desa Tigawasa"

Tujuan yang ingin dicapai melalui penelitian ini : (1) untuk mengetahui berbagai keunikan yang terkait dengan upacara penguburan mayat di Desa Tigawasa, (2) untuk mengetahui tradisi penguburan mayat di Desa Tigawasa, (3) untuk mengetahui sarana dan upakara yang digunakan dalam upacara penguburan mayat di Tigawasa 
Jurnal Widya Sastra Pendidikan Agama Hindu, Vol 4, No. 1, 2021

ISSN: 2656-7466

\section{METODE PENELITIAN}

Penelitian ini dilaksanakan karena adanya fenomena yang menarik di lapangan berupa masalah sosial, ketidakwajaran gejala sosial, dan ada sesuatu gejala yang bertentangan dengan teori perubahan sosial. Berdasarkan latar belakang masalah yang disajikan di depan bahwa fenomena ini kita dapatkan di desa Tigawasa, yakni tradisi penguburan mayat yang dilaksanakan oleh umat Hindu di desa ini sangat unik, berbeda dengan penguburan mayat yang dilaksanakan oleh umat Hindu di Bali pada umumnya. Mengingat fenomena ini terjadi di Desa Tigawasa, Kecamatan Banjar, Kabupaten Buleleng, maka lokasi inilah yang dipakai sebagai kancah penelitian.

Jenis data dalam penelitian ini adalah berupa informasi yang didapat dari beberapa informan dan juga berupa catatan dari beberapa sumber tertulis baik yang didapatkan di desa Tigawasa sebagai tempat penelitian maupun dari beberapa perpustakaan yang ada di Buleleng. Informasi atau keterangan yang didapatkan dari masyarakat Tigawasa merupakan data utama, sedangkan catatan-catatan, tulisantulisan yang terkait dengan obyek ini yang didapatkan dari buku-buku dan sumber tertulis lainnya sebagai data penunjang. Hal ini sesuai dengan apa yang sebutkan Bogdan dan Taylor (1975) (dalam Moleong;1993:3), metodelogi kualitatif sebagai prosudur penelitian yang menghasilkan data deskriptif berupa kata-kata tertulis atau lisan dari orang-orang dan perilaku yang dapat diamati. Penentuan informan digunakan purposive dengan teknik snowballing sampling, walaupun banyak sedikitnya informan tidak menentukan akurat dan tidaknya penelitian ( Basrowi dan Sukidin, 2002:11). Yang dijadikan informan adalah para tokoh masyarakat Desa Tigawasa diantaranya: Kepala Desa, Kelihan Adat, Pemangku Desa, Tukang Banten dan tokoh-tokoh masyarakat Tigawasa.

Dalam mengumpulkan data digunakan metode kepustakaan dan metode wawancara. Metode kepustakaan adalah mencari sumber-sumber untuk penelusuran teks-teks, naskah-naskah, buku-buku dan dokumen yang berkaitan dengan obyek penelitian di berbagai tempat. Tempat-tempat yang digunakan dalam penelusuran teks dalam penelitian ini antara lain perpustakaan STKIP Agama Hindu Singaraja, perpustakaan Daerah Kabupaten Buleleng, Gedong Kirtya Singaraja, dan perpustakaan pribadi.

Metode wawancara dengan teknik perekaman digunakan untuk mendapatkan data utama. Metode ini dilakukan dengan mengadakan wawancara dengan informan. Wawancara dilakukan secara mendalam, artinya informan diberikan keleluasaan untuk menjawab pertanyaan sesuai dengan pengetahuan yang dimilikinya sehingga tidak bersifat terbatas. Hal ini dimaksudkan untuk menggali seluas-luasnya dan sebanyak-banyaknya informasi dari informan. Dan untuk menghindari data yang hilang, maka wawancara yang dilakukan direkam dengan tape recorder di samping disertai dengan pencatatan-pencatatan yang dipandang sangat penting. Teknik wawancara mendalam digunakan dengan maksud agar dalam menjaring data agar dapat merekam tidak saja apa yang diketahui dan dialami oleh informan tetapi dapat juga diungkapkan apa yang jauh tersembunyi pada dirinya. Selain itu melalui teknik wawancara ini bisa diungkapkan berbagai informasi yang bersifat lintas waktu yang berkaitan dengan masa lampau, sekarang dan yang akan datang (Faisal, 1990). Dan dalam rangka menunjang kelancaran wawancara disusun pedoman wawancara yang 
Jurnal Widya Sastra Pendidikan Agama Hindu, Vol 4, No. 1, 2021

ISSN: 2656-7466

memuat pokok pokok-pokok masalah yang akan ditanyakan dan pengembangannya dilakukan pada saat wawancara.

Data yang didapat akan dianalisis secara terus menerus sejak awal penelitian ini dilaksanakan sampai dengan akhir penelitian. Untuk mencek kebenaran hasil analisis dan hasil penelitian maka akan dikonfirmasikan kepada informan atau masyarakat Tigawasa. Adapun teknik analisis yang digunakan disesuaikan dengan jenis data, sifat data, dan tujuan penelitian yang telah dirumuskan. Bertitik tolak dari hal-hal tersebut, maka teknik analisis data yang digunakan dalam penelitian ini adalah model analisis etnografi (ethnography analysis), yang meliputi: (1) analisis domain (domain abnalysis), (2) analisis taksonomik (taxonomic analysis), dan (3) analisis komponensial (componential analysis) (Sadewo, 2003:180-184). Dalam penelitian ini data yang diperoleh dari kancah penelitian berupa informasi atau keterangan, maka penyajian hasil penelitian yang digunakan adalah metode deskriptif.

\section{HASIL DAN PEMBAHASAN}

\section{Keunikan-keunikan Terkait dengan Penguburan Mayat di Tigawasa}

Tigawasa adalah salah satu desa Baliage atau Bali Mula di Kabupaten Buleleng. Oleh karena itu, di desa ini akan dijumpai berbagai hal yang berbeda dengan desa-desa dataran yang ada di Bali. Terkait dengan penguburan Mayat ada beberapa hal yang bersifat unik sebagai berikut.

1). Keberadaan Kuburan (Setra)

Keberadaan kuburan di desa Tigawasa sangat disakralkan, karena berdasarkan awig-awig yang tidak tertulis, semua orang baik warga desa Tigawasa maupun orang luar dilarang atau tidak diperkenankan masuk areal kuburan (setra). Terkait dengan hal ini masyarakat desa Tigawasa memiliki kepercayaan bahwa apabila ada warga yang berani masuk ke areal kuburan, di luar waktu atau tidak saat menguburkan mayat, maka yang bersangkutan akan mendapat celaka. Kepercayaan ini juga berdampak pada sesi penguburan, di mana umumnya warga banjar atau warga desa adat di desa lain pada saat menguburkan ke kuburan ikut mengantar mayat yang dikuburkan, sehingga saat menguburkan melibatkan masyarakat desa umum. Hal ini tidak terjadi di Tigawasa, saat menguburkan hanya diantar oleh keluarga dadya yang bersangkutan atau pretisentananya saja, dadya lain tidak ikut mengantar, karena tidak berani memasuki areal kuburan. Terkait dengan keyakinan ini juga berdampak pada pembuatan lubang (bambang) kuburan. Desa lain di Bali, umumnya keluarga yang mempunyai hajat membuat bambang sehari sebelum penguburan mayat dilaksanakan. Namun di desa Tigawasa, membuat lubang kuburan hanya saat menguburkan. Tidak ada kegiatan atau aktivitas di kuburan sebelum dan sesudah penguburan. Semua harus dilaksanakan pada saat menguburkan. Setelah penguburan semua upacara yang terkait dengan orang yang dikuburkan seperti pemberian makanan (ngejot/munjung) dilaksanakan dari rumah yang bersangkutan. Demikian pula beberapa sarana yang diperlukan saat menguburkan seperti teratag, yang terbuat dari kayu, puung dan belibit yang terbuat dari bambu, harus dicari di areal kuburan dan dibuat pula pada saat penguburan itu dan tidak diperkenankan membawa dari rumah. Mengingat areal kuburan tidak boleh ada orang yang masuk, maka keberadaan kuburan (setra) Tigawasa tidak disertai dengan pura Dalem dan pura Prajapati, seperti setra-setra desa adat yang lain. Pada 
umumnya di Bali setiap kuburan/Setra selalu terkait atau disertai dengan pura Dalem dan pura Prajapati. Mengingat di Tigawasa tidak diperkenankan masuk areal kuburan atau Setra, maka keberadaan kuburan itu tidak disertai dengan pura Dalem dan pura Prajapati. Hal lain yang cukup unik dari kuburan/Setra Tigawasa adalah luas areal kuburannya. Luas areal kuburan/setra Tigawasa sangat luas kurang lebih sebanyak 12 hektar. Kalau kita bandingkan luas kuburan ini dengan kuburan di desa-desa Bali dataran tampaknya tidak akan kita dapatkan luas kuburan yang sebesar 12 hektar. Mengingat begitu luasnya, maka setiap klen/dadya memiliki petak-petak tertentu dan tidak bercampur dengan klen/dadya lain seperti di kuburan desa adat lainnya. Mengingat areal kuburan begitu luas, maka Areal ini sesungguhnya dapat dipandang sebagai hutan belantara, lebih-lebih adanya larangan masuk kuburan, maka keberadaan kuburan Tegawasa sebagai pendukung kelestarian lingkungan hutan seperti keberadaan hutan lindung.

\section{2). Penentuan Waktu Penguburan (Dewasa)}

Terkait dengan penguburan mayat ada awig-awig yang mengikat warga desa Tigawasa, yakni mayat tidak boleh didiamkan di rumah duka lebih dari 24 jam. Kalau ada orang meninggal sebelum jam 12 malam, maka besoknya mayat tersebut harus sudah dikuburkan. Dampak dari adanya aturan ini, tidak ada orang mencari dewasa ayu (hari baik) untuk menguburkan mayat seperti yang dilakukan masyarakat Hindu di Bali umumnya. Dengan adanya aturan ini, di Tegawasa tidak ada orang mendiamkan mayat di rumah duka berhari-hari seperti di desa adat lainnya di Bali. Aturan ini berdampak efektif dan ekonomis bagi warga Tegawasa, kalau mendiamkan mayat berhari-hari tentu tetangga serta warga lain akan datang berkunjung ke rumah duka sebagai rasa simpati dan dengan kedatangan ini akan menambah beban keluarga duka, karena harus menyiapkan suguhan dan malam-malamnya harus begadang karena ada mayat karena itu semua itu akan melelahkan keluarga duka, sehingga aturan ini bersifat positif bagi warga.

\section{2 ,Tradisi atau Tatacara Penguburan Mayat di Desa Tigawasa}

Tatacara penguburan mayat di desa Tigawasa terdiri dari beberapa tahapan, yaitu: 1). Upacara saat meninggal ( Wawu lampus), 2). Upacara memandikan mayat (nyiramang); 3). Upacara mengusung mayat ke kuburan; 4). Upacara pembelian liang kubur dan 5). Upacara penguburan.

\section{1). Upacara saat meninggal ( Wawu lampus)}

Upacara yang dilaksanakan paling awal adalah upacara pada saat seseorang meninggal. Terkait dengan upacara ini ada beberapa rangkaian yang dilaksanakan antara lain: a. penggantian pakaian mayat dari pakaian yang dipakainya sebelum yang bersangkutan meninggal menggantinya dengan pakaian baru. Apabila yang meninggal laki-laki maka akan dipakaikan pakaian adat laki-laki selengkapnya (arangsukan seperti kamen, saput dan udeng), apabila yang meninggal perempuan, maka pakaian yang dikenakan kamen, tapih, selendang/kamencerik; b. mayat ditutup (dirurubi) dengan kain/kamen; c. mempersembahkan sagi-sagi berupa nasi yang beralaskan mangkok dan terakhir d. mengumandangkan lagu-lagu kematian yang disebut Mengelelanjatan. Dengan telah dilaksakanannya mengelelanjatan ini berarti upacara wawu lampus ini telah selesai.

2). Upacara memandikan mayat (nyiramang) 
Sebelum diuraikan rangkaian upacara Nyiraman ini, perlu ditegaskan bahwa tempat upacara ini dilaksanakan di dalam kamar. Berbeda dengan nyiraman mayat pada umumnya yang dilaksanakan di atas pepaga di halaman rumah yang bersangkutan, tetapi di Tegawasa dilaksanakan di dalam kamar yang bersangkutan. Upacara memandikan mayat, meliputi beberapa tahapan, yaitu: mengkramas (ngambuhin) mayat dari santan; menyisir mayat dengan petat, menggosok gigi mayat dari abu pembakaran sirih, beras dan garam[ memandikan mayat dari air yang diambil dari perempatan dengan menggunakan daun sembung; menyemprotkan (mesui) sebanyak tiga kali; memasang gantal jeriji yang terbuat dari daun sirih yang diikat dengan benang berisi 10 buah uang kepeng sebagai penutup kemaluan; meletakan waja di mulut; meletakan kaca di mata; meletakan tetebus di jari tangan dan kaki yang terbuat dari benang putih; meletakan bantal (gegaleng) di leher dari 100/200 uang kepeng; meletakan 75 uang kepeng di pinggang (bebokong); meletakan 50 uang kepeng di kaki; melaknakan tradisi makan sirih pada mayat dengan menekan-nekan dahi mayat tiga kali sebagai lambang Brahma, Wisnu dan Siwa dengan mengucapkan doa, " bangket base, bangket apuh, apang leket dini, leket ditu, nyai/cai memarekan" ; menggulung mayat dengan tikar dan kain putih di atasnya diletakan pakaian mayat selengkapnya ( kamen, saput, udeng untuk laki-laki; kamen, tapih, dan mencerik untuk perempuan); menghaturkan sagi-sagi (banten arepan berupa nasi, sayur, kopi, kue dan lain-lain) dan terakhir dari upacara nyiramang ini mendendangkan kekidungan pitra yadnya yang disebut dengan melelanjatan.

\section{3). Upacara mengusung mayat ke kuburan (setra)}

Setelah upacara memandikan mayat selesai dilaksanakan di rumah duka, acara selanjutnya adalah mengusung jenasah dari rumah duka ke kuburan. Tidak ada upacara yang dilaksanakan dalam perjalanan ke kuburan ini seperti memutar tiga kali dan menghamburkan uang kepeng di setiap perempatan yang dilalui seperti yang dilakukan di desa adat lain. Di desa Tigawasa upacara mengusung mayat ini tanpa ada tahapan yang lain dengan catatan, jenasah tidak boleh diturunkan baik di jalan maupun di kuburan sebelum masuk liang kubur.

\section{4). Upacara pembelian liang kubur}

$\mathrm{Di}$ atas sudah disebutkan bahwa dengan adanya awig-awig tidak boleh memasuki kuburan selain saat menguburkan mayat atau ngaben, maka pada saat jenasah sampai di kuburan tentu liang kuburan belum ada. Oleh karena itu, saat sampai di kuburan, jenasah harus digotong oleh sanak keluarga selama masa pembuatan liang kubur. Umumnya ukuran liang kubur yang dibuatkan lebar biasanya sebahu dan panjangnya sesuai dengan tinggi orang yang meninggal dan kedalamnya biasanya sepinggang orang dewasa. Apabila liang kubur telah selesai jenasah tidak langsung diturunkan ke liang kubur, melainkan harus diawali dengan upacara pembelian liang kubur. Upacara ini dengan menggunakan upakara atau sarana uang kepeng (pis bolong) yang disebarkan di dalam liang kubur, yang mengandung makna meminta ijin kepada penguasa kuburan yang biasa disebut Sedahan Setra.

\section{5). Upacara penguburan}

Setelah berakhirnya upacara pembelian liang kubur dilanjutkan dengan upacara puncak, yaitu upacara penguburan. Catatan yang perlu dipegang saat menguburkan ini, adalah mayat bagian atas diusahakan tidak langsung mengenai tanah. Oleh karena itu, setelah mayat diletakan di liang kubur, diatasnya diletakkan 
balok-balok kayu yang disebut dengan Blitbit, yang dipasang secara berjejer seperti memasang usuk rumah. $\mathrm{Di}$ atas Blitbit ditaruh pakaian yang dimiliki yang bersangkutan masih hidupnya dan disertai pula dengan uang atau uang kepeng yang diberikan oleh sanak keluarga sebagai bekal yang bersangkutan di alam baka. Kemudian di atasnya ditaruh daun penyalin yang lebih dikenal dengan daun Wi semacam atap, yang pada dasarnya menghindari jenasah bersentuhan langsung dengan tanah. Apabila hal ini kita kaji tentu keyakinan ini terkait pula dengan sektesekte yang pernah berkembang pada zaman dahulu di Bali. Terkait dengan hal ini Jendra (2007:59-60) mengatakan, dalam perkembangan agama Hindu di Bali sejak abad-10 sudah berafiliasi pada salah satu sampradaya, sekte atau paksa yang berkembang. Terkait dengan hal ini dalam lontar Sad Agama disebutkan ada 6 sekte/paksa yang berkembang di Bali saat itu antara lain: sekte Sambhu, sekte Brahmana, sekte Indra, sekte Bayu, sekte Wisnu dan sekte Kala. Dalam perkembangan berikutnya, atas dasar hasil penelitian R. Goris (1974) yang diungkapkan dalam bukunya yang berjudul Sekte-sekte di Bali, disebutkan bahwa ada 9 sekte yang berkembang di Bali antara lain: Siwa Sidhanta, Pasupata, Bhairawa, Waisnawa, Sogata/Budha, Brahmana, Rsi, Sora/Surya, dan Ganapati. Atas dasar hal ini, maka dapat diprediksi bahwa apa yang dilakukan oleh umat Hindu di desa Tegawasa dalam menguburkan mayat dipengaruhi oleh salah satu sekte yang berkemang sebelum agama Hindu Majapahit yang mempengaruhi Bali. Dari sistem keyakinan yang dianutnya diperkirakan bahwa tatacara penguburan mayat ini dipengaruhi oleh sekte Sambhu. Hal ini diperkuat lagi di mana dalam penguburan mayat ini tidak memilih hari baik dan menggunakan daun sembung dalam upacara penguburan. Sebagai bandingan ditemukan sisa-sisa peninggalan dari sekte Bayu, yang masih dipertahankan oleh masyarakat desa Trunyan, dalam menepatkan mayat dengan begitu saja dan tidak ditanam seperti desa-desa lainnya di Bali (Jendra, 1974:61)

Setelah pemasangan Blitbit, barulah mayat dikubur dengan tanah. Tanah yang dipakai menimbun mayat tidak dipadatkan/diinjak-injak seperti penguburan di desa lain, melainkan ditimbun begitu saja dan tanah timbunan itu dibentuk seperti tubuh manusia. Setelah itu dipasang/ditamcapkan 3 buah pepuung, yaitu di bagian kepala 1 , di bagian tengah 1 dan di bagian kaki 1. Selanjutnya dipasang 3 buah bambu runcing dengan ukuran $10-12$ secara silang. Tahap berikutnya, memakan sirih (base) dengan cara daun sirih dicelupkan ke dalam air dan airnya itu dituangkan di bagian kepala kuburan. Yang terakhir Melelanjatan sebanyak tiga kali dan dengan berakhirnya Melelanjatan ini berarti upacara penguburan ini telah berakhir dan sanak keluarga boleh meninggalkan upacara kembali ke rumahnya masing-masing.

\section{Sarana dan Upakara yang digunakan dalam Upacara Penguburan Mayat}

Ada beberapa sarana dan upakara (banten) yang digunakan dalam upacara penguburan mayat di desa Tigawasa. Terkait dengan pelaksnaan penguburan mayat di desa Tigawasa sarana yang digunakan di samping menggunakan banten/upakara. Ada beberapa sarana yang digunakan antara lain: 1). Ambuh, terbuat dari santan untuk sarana mengramasi mayat; 2). Sisir/petat, untuk menyisir mayat setelah dikramasi; 3). Sisig, terbuat dari arang daun sirih, beras, garam untuk membersihkan gigi mayat; 4). Waja, serpihan wajan, yang diletakan di atas gigi yang bermakna agar kelak reinkarnasi kembali memiliki gigi yang kuat; 5). Cermin/meka, ditempatkan di mata yang mengandung makna kelak bila reinkarnasi memiliki mata yang jelas; 6). Uang kepeng (pis bolong), digunakan sebagai bantal, tetebus liang kuburan, sarana 
gantal jeriji, bekal bagi yang meninggal dan lain-lain; 7). Daun sirih, sarana membuat gantal jeriji untuk mutup kemaluan mayat; 8). Benang, untuk mengikat jari-jari tangan dan kaki mayat ; 9). Mesui, yang digunakan untuk menolak bala dan kelak kalau reinkarnasi tidak sakit-sakitan; 10). Daun sembung, sebagai sarana membersihkan air saat memandikan mayat sebagai pengganti anduk; 11). Pepage, tempat mengusung jenasah yang terbuat dari bambu, sebagai petunjuk agar yang meninggal dapat segera menemukan jalan yang dituju ; 12). Daun penyalin/daun wi, digunakan untuk menutup mayat agar mayat tidak bersentuhan langsung dengan tanah; 13). Blitbit, terbuat dari ikatan bambu yang fungsinya sama dengan daun penyalin agar mayat tidak bersentuhan langsung dengan tanah; 14). Puung; terbuat dari bambu yang diruncingkan, yang melambangkan ikatan Tri Angga; 15). Cepu, terbuat dari anyaman bambu sebagai tempat untuk meletakan alat-alat upakara 16). Air, digunakan sebagai pelengkap pembersihan sebagaimana kegunaan air dan 27). Pakaian, digunakan baik sebagai penghiyas jenasah saat upacara (pakaian aransukan) maupun pakaian yang dimiliki yang meninggal saat masih hidup. Di samping sarana, digunakan juga beberapa upakara/banten, antara lain: 1). Sesagi, sejenis banten punjung yang dipersembahkan 3 kali dalam sehari dapat dipandang sebagai makanan sebagaimana yang bersangkutan semasih hidup; 2). Banten aleman, sebagai lambang tri angga (bayu, sabda, idep) ; dan 3). Canang gantal sebanyak 21 yang dirangkai sedemikian rupa, terbuat dari daun sirih (Wisnu), buah-buahan (Brahma), pamor (Iswara), Gambir (Mahadewa) dan tembako (Siwa).

Sarana dan banten/upakara yang dugunakan dalam penguburan mayat di desa Tigawasa sangat sederhana dan prosesnya pun sangat sederhana (simple). Sarana yang digunakan jumlahnya mungkin tidak terlalu jauh bedanya, walaupun istilah dan alat-alat yang digunakan berbeda. Yang sangat menyolok adalah dalam menggunakan banten. Dalam seluruh proses penguburan, di Tegawasa hanya menggunakan tiga jenis banten, yaitu 1). Sesagi, sejenis banten punjung ; 2). Banten aleman, sebagai lambang tri angga (bayu, sabda, idep) ; dan 3). Canang gantal sebanyak 21. Dalam penguburan umat Hindu di Bali tentu menggunakan jenis dan jumlah banten jauh lebih banyak. Misalnya pada saat mempersembahkan banten arepan ada beberapa jenis banten yang diaturkan seperti bubur pirate, banten nasi angkeban, saji-saji, selanjutnya dalam Mapegat dihaturkan banten sambutan. Demikian pula dalam menggunakan air suci/tirta, ada beberapa tirta yang digunakan seperti tirta pembersihan, pengelukatan, tirta merajan, tirta kawitan, tirta kahyangan tiga dan lain-lain (Team Penyusun; 2007:170-179). Perbedaan seperti ini harus disadari karena semenjak abad ke-8 agama Hindu yang berkembang di Bali secara umum menganut Siwa Sidhanta yang diprakarsai oleh Danghyang Markandeya, setelah Beliau melakukan penanaman Panca Datu (emas, perak, tembaga, besi dan permata) di pelinggih-pelinggih pura Besakih, Beliau mengajarkan penerapan agama Hindu dalam bentuk ritual: Surya Sewana, Bebali (banten) dan Pecaruan. Selanjutnya diteruskan oleh penerusnya, Mpu Sangkulputih, dengan melengkapi berbagai variasi jenis banten dan menambahkan unsur-unsur tumbuh-tumbuhan lainnya seperti daun sirih, daun pisang daun janur; berbagi jenis buah-buahan seperti pisang, kelapa, mangga dan buah lainnya serta berbagai jenis biji-bijian seperti beras, injin, dan kacang-kacangan, sehingga tercipta berbagai jenis banten seperti canang sari, canang raka, daksina, peras, penyeneng dan sebagainya (Pasek Gunawan; 2012:105-106). 
Jurnal Widya Sastra Pendidikan Agama Hindu, Vol 4, No. 1, 2021

ISSN: 2656-7466

\section{KESIMPULAN}

Berdasarkan uraian di atas, maka dapat ditarik kesimpulan sebagai hasil penelitian sebagai berikut.

1. Keunikan-keunikan Penguburan Mayat di Tigawasa: (1) tidak boleh membuat liang kubur sebelum upacara penguburan, karena kuburan tidak boleh dimasuki kecuali ada upacara penguburan/ngaben. (2) kuburan desa Tegawasa tidak disertai pura Dalem dan pura Prajapati, karena adanya awig-awig pelarangan memasuki wilayah kuburan. (3) sebagian sarana penguburan seperti bambu, kayu dan dedaunan yang diperlukan saat menguburkan harus dicari di areal kuburan tidak boleh dibawa dari rumah duka. (4) waktu penguburan tidak mencari dewasa (hari baik) karena ada awig-awig desa, mayat tidak boleh didiamkan di rumah lebih dari 24 jam.

2. Tatacara penguburan mayat di desa Tigawasa terdiri dari beberapa tahapan, yaitu: (1). Upacara saat meninggal ( Wawu lampus), (2). Upacara memandikan mayat (nyiramang); (3). Upacara mengusung mayat ke kuburan; (4). Upacara pembelian liang kubur dan (5). Upacara penguburan.

3. Sarana yang digunakan dalam penguburan mayat desa Tegawasa antara lain: 1). Ambuh; 2). Sisir(petat; 3). Sisig, 4). Waja; 5). Cermin/meka; 6). Uang kepeng; 7). Daun sirih; 8). Benang; 9). Mesui; 10). Daun sembung; 11). Pepage; 12). Ayam; 13). Daun penyalin/daun wi; 14). Blitbit; 15). Puung; 16). Cepu; 17). Air dan 20). Pakaian dan banten yang digunakan: 1). Sesagi (banten Punjung), 2). Banten aleman, dan 3). Canang gantal 21 buah. 
Jurnal Widya Sastra Pendidikan Agama Hindu, Vol 4, No. 1, 2021

ISSN: 2656-7466

\section{DAFTAR PUSTAKA}

Agus Salim, (Penyunting) (2001). Teori dan Paradigma Penelitian Sosial (dari Denzin Guba dan Penerapannya), Penerbit: PT. Tiara Wacana Yogyakarta.

Alwasilah, A. Chaedar (2002). Pokoknya Kualitatif, Dasar-dasar Merancang dan Melakukan Penelitian Kualitatif, Penerbit: Pt Dunia Pustaka Jaya dan Pusat Studi Sunda, Jakarta.

Ardana, Prof. Drs. I Gusti Gde. (1988/1989). Pura Kahyangan Tiga, Penerbit: Pemda Tingkat I Bali, Proyek Penyuluhan dan Penerbitan Buku Agama, Denpasar.

Bakker, Dr. Anton \& Drs. Achmad Charris Zubair (1994) Metodelogi Penelitian Filsafat, Penerbit: Kanisius, Yogyakarta.

Bryan \& Jurner (2006). Agama \& Teori Sosial, Penerbit: IRCiSod, Yogyakarta.

Dasim Mathar, MA. DR. H. Moch. (2005). Sejarah, Teologi dan Etika, Agamaagama. Penerbit: Dian/Interfidei, Yogyakarta.

Gunadha, M.Si, Prof. Dr. Ida Bagus (2008-2009), Pemberdayaan Desa Pakraman, Sebagai Strategi Kebertahanan Adat, Budaya dan Agama Hindu Bali. Pembinaan Desa Pekraman, Kerja sama UNHI Denpasar \& Kanwil Departemen Agama Propinsi Bali.

Kutha Ratna, SU. Prof. Dr. Nyoman (2010) Metodelogi Penelitian Kajian Budaya dan IImu Sosial Humaniora pada Umumnya, Penerbit: Pustaka Pelajar, Yogyakarta.

Mandrasuta, Ngakan Made. (2006). Hindu Akan Ada Selamanya, Penerbit: Media Hindu.

Moleong, MA. Dr. Lexy J. (1993). Metodologi Penelitian Kualitatif, Penerbit: PT. Remaja Rosdakarya, Bandung.

Nyoka (1990) Sejarah Bali, Penerbit: Toko Buku Ria, Denpasar.

Siagian, Dra. Seno Harbangan, (1989) Agama-Agama di Indonesia (Cetakan Ke-II), Penerbit: Catya Wacana, Semarang.

Singarimbun, Masri \& Sofian Effendi (editor) (1989) Metode Penelitian Survai, Penerbit: LP3ES, Jakarta.

Simpen, AB. Wayan (1986). Adat Kuna, Catur Desa (Tiga Wasa, Sidatapa, Pedawa, Cempaga) Penerbit: -

Soebandi, Ktut (2008). Riwayat Merajan di Bali, Penerbit: CV. Kayumas Agung, Denpasar.

Soebandi, Ktut (1981). Pura Kawitan/Padharman dan Panyungsungan Jagat, Penerbit: CV. Kayumas, Denpasar.

Suasthawa Dharmayuda, SH. I Made (1995). Kebudayaan Bali, Pra Hindu, Masa Hindu dan Pasca Hindu, Penerbit: CV. Kayumas Agung, Denpasar. 
Jurnal Widya Sastra Pendidikan Agama Hindu, Vol 4, No. 1, 2021

ISSN: 2656-7466

Sudarsana,MBA.MM. Drs. I.B.Putu (2000). Ajaran Agama Hindu Manifestasi Sang

Hyang Widhi, Penerbit: Yayasan Dharma Acarya, Percetakan Mandara sastra, Denpasar.

Sudikan,MA. Dr. Setya Yuwana (2001) Metode Penelitian Kebudayaan, Penerbit: Unesa Unipress bekerjasama dengan Citra Wacana, Surabaya.

Sugeng Pujilaksono. (2006). Petualangan Antropologi, Sebuah Pengantar IImu Antropologi, Pnerbit: UPT. Penerbitan Universitas Muhammadiyah, Malang.

Suhardana. Drs. K.M. (2006). Menelusuri Kawasan Suci Hindu Berdasarkan Kitab Suci Weda. Penerbit: PT. Empat Warna Komunikasi, Denpasar.

Sutaba, I Made (1980) Prasejarah Bali, Penerbit: B.U Yayasan Purbakala Bali.

Swami Prabhavananda, (2006). Agama Weda dan Filsafat, Penerbit: Paramita Surabaya

Tantera Keramas, Prof. Dr. Dewa Made (2008) Metode Penelitian Kwalitatif dalam Ilmu Agama dan Kebudayaan; Penerbit: Paramita, Surabaya.

Team Penyusun, (1988). Himpunan Keputusan Seminar Kesatuan Tafsir Terhadap Aspek-Aspek Agama Hindu I-IX, Penerbit: Parisada Hindu Dharma Pusat.

Team Penyusun, (1985/1986). Sejarah Perkembangan Agama Hindu di Bali, Penerbit: Proyek Penyuluhan Agama dan Penerbitan Buku Agama (1985/1986), Pemerintah Daerah Tingkat I Bali, Denpasar.

Tim Penyusun, (2005). Pedoman Pembinaan Lembaga Keagamaan Hindu, Penerbit: Paramita, Surabaya.

Tonjaya, I Ny. Gd. Bandesa K. (1982). Asta Kosali, Penerbit: Toko Buku Ria, Denpasar.

Triguna, Ida Bagus Gede Yudha, (2001). Mengapa Bali Unik; Penerbit: Pustaka Jurnal Keluarga, Jakarta.

(2001). Strategi Hindu; Penerbit: Pustaka Jurnal Keluarga, Jakarta.

Pendit, Nyoman S. Sri Chandrasekharendra Saraswati (1993). Aspek-aspek Agama Hindu, Seputar Weda dan Kebajikan. Penerbit: Pustaka Manik Geni, Jakarta.

Pendit, Nyoman S. (1995). Hindu Dalam Tafsir Modern, Penerbit : Yayasan Dharma Naradha, Denpasar.

Pidarta, Prof. Dr. Made (2007). Esensi Agama Hindu, Edisi III, Penerbit: Enesa University Press

Purwita, Drs. Ida bagus Putu, (1984). Desa Adat dan Banjar di Bali, Penerbit: Percetakan Kawi Sastra, Denpasar.

Watra, I Wayan (2006) Dasar Filsafat Agama-Agama, dalam Rangka Menciptakan Keindahan Multikulturisme Di Indonesia, Penerbit: Paramita, Surabaya. 
Jurnal Widya Sastra Pendidikan Agama Hindu, Vol 4, No. 1, 2021

ISSN: 2656-7466

Widana, I Gusti Ketut (2008) Mengenal Budaya Hindu di Bali (Sudah ada Merajan kok Dirikan Kamar Suci?), Penerbit: Pustaka Balipost, Denpasar.

Widhiasa, Drs. Putu (1996), Pula-Pali Wong Mati; Penerbit Percetakan Surya Dewata, Singaraja Bali. 